\title{
HORMONES AND SPORT
}

\section{Proof of the effect of testosterone on skeletal muscle}

\author{
S Bhasin, L Woodhouse and T W Storer ${ }^{1}$ \\ Division of Endocrinology, Metabolism, and Molecular Medicine, Charles R Drew University of Medicine and Science, Los Angeles, California 90059, USA \\ ${ }^{1}$ Laboratory for Exercise Sciences, El Camino College, Torrance, California, USA \\ (Requests for offprints should be addressed to S Bhasin, Division of Endocrinology, Metabolism, and Molecular Medicine, Charles R Drew University of \\ Medicine and Science, Los Angeles, California 90059, USA)
}

\begin{abstract}
In spite of the widespread abuse of androgenic steroids by athletes and recreational body-builders, the effects of these agents on athletic performance and physical function remain poorly understood. Experimentally induced androgen deficiency is associated with a loss of fat-free mass; conversely, physiologic testosterone replacement of healthy, androgen-deficient men increases fat-free mass and muscle protein synthesis. Testosterone supplementation of HIV-infected men with low testosterone levels and of older men with normally low testosterone concentrations also increases muscle mass. However, we do not know whether physiologic testosterone replacement can
\end{abstract}

improve physical function and health-related quality of life, and reduce the risk of falls and disability in older men or those with chronic illness. Testosterone increases maximal voluntary strength in a dose-dependent manner and thus might improve performance in power-lifting events. However, testosterone has not been shown to improve performance in endurance events. The mechanisms by which testosterone increases muscle mass are not known, but probably involve alterations in the expression of multiple muscle growth regulators.

Journal of Endocrinology (2001) 170, 27-38
The abuse of androgenic steroids by athletes and the proposed anabolic applications of these agents in sarcopenia (loss of muscle mass and strength) associated with aging or chronic illness is based on the premise that these agents increase muscle mass and improve measures of skeletal muscle performance, and that androgen-induced changes in skeletal muscle performance translate into improvements in athletic performance and health-related outcomes (Fig. 1). The premise remains unsubstantiated. There is agreement that testosterone supplementation increases muscle mass and maximal voluntary strength in a variety of clinical and experimental paradigms (Tenover 1992, Urban et al. 1995, Bhasin et al. 1996, 1997, Brodsky et al. 1996, Katznelson et al. 1996, Wang et al. 1996, 2000, Synder et al. 2000), but we do not know whether testosterone improves athletic performance or healthrelated outcomes, and whether beneficial effects of androgens can be achieved without significant long-term adverse effects.

Opinion as to the effects of testosterone on the muscle in healthy eugonadal men has been enormously controversial for more than five decades (Wilson 1988, Bardin 1996, Casaburi et al. 1996b). The athletes who abuse androgenic steroids believe fervently that these drugs increase muscle mass and strength; however, the academic community decried their use, citing lack of verifiable evidence (Wilson 1988, Bardin 1996, Casaburi et al. 1996b). The historical aspects of the use of androgenic/ anabolic steroids have been extensively reviewed (Wilson 1988, Bardin 1996). Although their use is most common among weight-lifters and heavy throwers, almost all types of athletes whose event requires explosive strength, including football players, swimmers and track and field athletes, have been known to use steroids. Their use has spread to high-school athletes and to amateur bodybuilders. Disqualification of highly celebrated athletes in recent years has focused substantial media attention on this issue.

Considerable debate has raged in the academic community for five decades on whether androgenic steroids had anabolic effects on the muscle, due in part to the shortcomings of previous studies; several reviews have discussed these study design issues (Wilson 1988, Bardin 1996). For instance, many of the studies that examined the effect of androgenic steroids were neither blinded nor randomized. Some studies included competitive athletes, whose desire to win at any cost prevent them from complying with a standardized regimen of diet and 


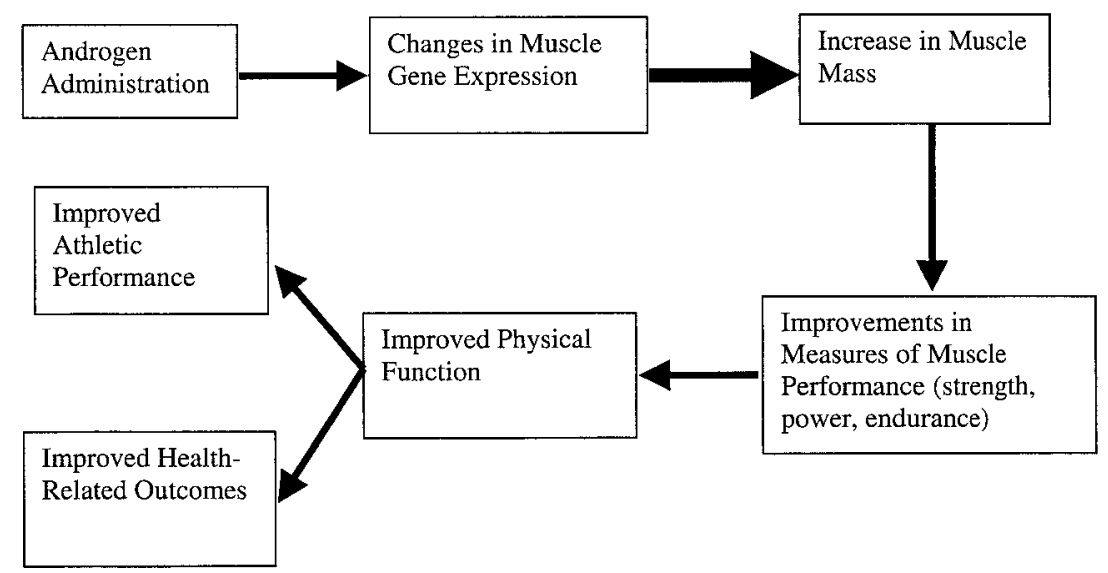

Figure 1 Rationale for the abuse of androgenic steroids by athletes and their potential application as anabolic therapy for sarcopenia associated with old age and chronic illness. This is based on the premise that these agents induce alterations in muscle gene expression that result in increased muscle mass and improved muscle performance. It is further assumed that increased muscle mass and performance will translate into improved physical function, athletic performance and health-related outcomes. Although androgenic steroids have been shown to increase muscle mass and maximal voluntary strength, their effects on physical function, health-related outcomes and athletic performance have not been rigorously studied. The heavy arrow indicates areas of certainty, and lighter arrows indicate areas of uncertainty.

exercise. Nutritional intake was not controlled in many of the studies; changes in energy and protein intake might have had independent effects on nitrogen balance. Exercise stimulus was not standardized and, in some studies, the participants were allowed to exercise ad libitum. Therefore, the effects of androgen administration could not be separated from the effects of resistance exercise training. Most of the studies performed before the 1980s used relatively small doses of androgenic steroids, equivalent to or less than the replacement dose of testosterone used for the treatment of androgen-deficient men. In contrast, athletes use supraphysiological doses of androgenic steroids. Because of these problems of study design, the results of these previous studies were inconclusive. With the advent of magnetic resonance imaging and more refined methods for the assessment of body composition, it has become possible to detect small changes in muscle volume and fat-free mass with a greater degree of precision and accuracy than was feasible before. Consequently, studies published in the past 6 years by a number of groups have now established that testosterone supplementation does increase muscle mass and strength (Bhasin et al. 1996, Brodsky et al. 1996, Katznelson et al. 1996, Wang et al. 1996, 2000, Snyder et al. 2000).

\section{A reduction in serum testosterone is associated with decreased fat-free mass}

Healthy, hypogonadal men have lower fat-free mass and higher fat mass compared with those of age-matched eugonadal men (Katznelson et al. 1996, 1998). Mauras et al. (1998) have reported that experimental suppression of serum testosterone by administration of a gonadotropinreleasing hormone $(\mathrm{GnRH})$ agonist analog in healthy young men is associated with a significant reduction in fat-free mass, an increase in fat mass, and a decrease in fractional muscle protein synthesis. An age-associated decline in serum testosterone concentrations correlates with decreased appendicular muscle mass and reduced lower extremity strength in white and in AfricanAmerican men (Morley et al. 1993, 1997).

\section{Effects of physiologic testosterone replacement in healthy, young hypogonadal men}

Testosterone replacement increases nitrogen retention in castrated males of several animal species (Kochakian et al. 1950), eunuchoidal men, boys before puberty, and women (Kenyon et al. 1940). Several recent studies have reexamined the effects of testosterone on body composition and muscle mass in hypogonadal men in more detail. We administered $100 \mathrm{mg}$ testosterone enanthate intramuscularly weekly for 10 weeks to seven hypogonadal men after a 10-12 week period of androgen withdrawal (Bhasin et al. 1997). Testosterone replacement was associated with a $4.5 \pm 0.6 \mathrm{~kg}(P=0.005)$ increase in body weight because of a $5.0 \pm 0.8 \mathrm{~kg}(P=0.004)$ increase in fat-free mass, estimated from underwater weight, whereas body fat did not change. Similar increases in fat-free mass were observed using the deuterium water dilution method. Arm 
Table 1 Effects of testosterone replacement on body composition in hypogonadal men

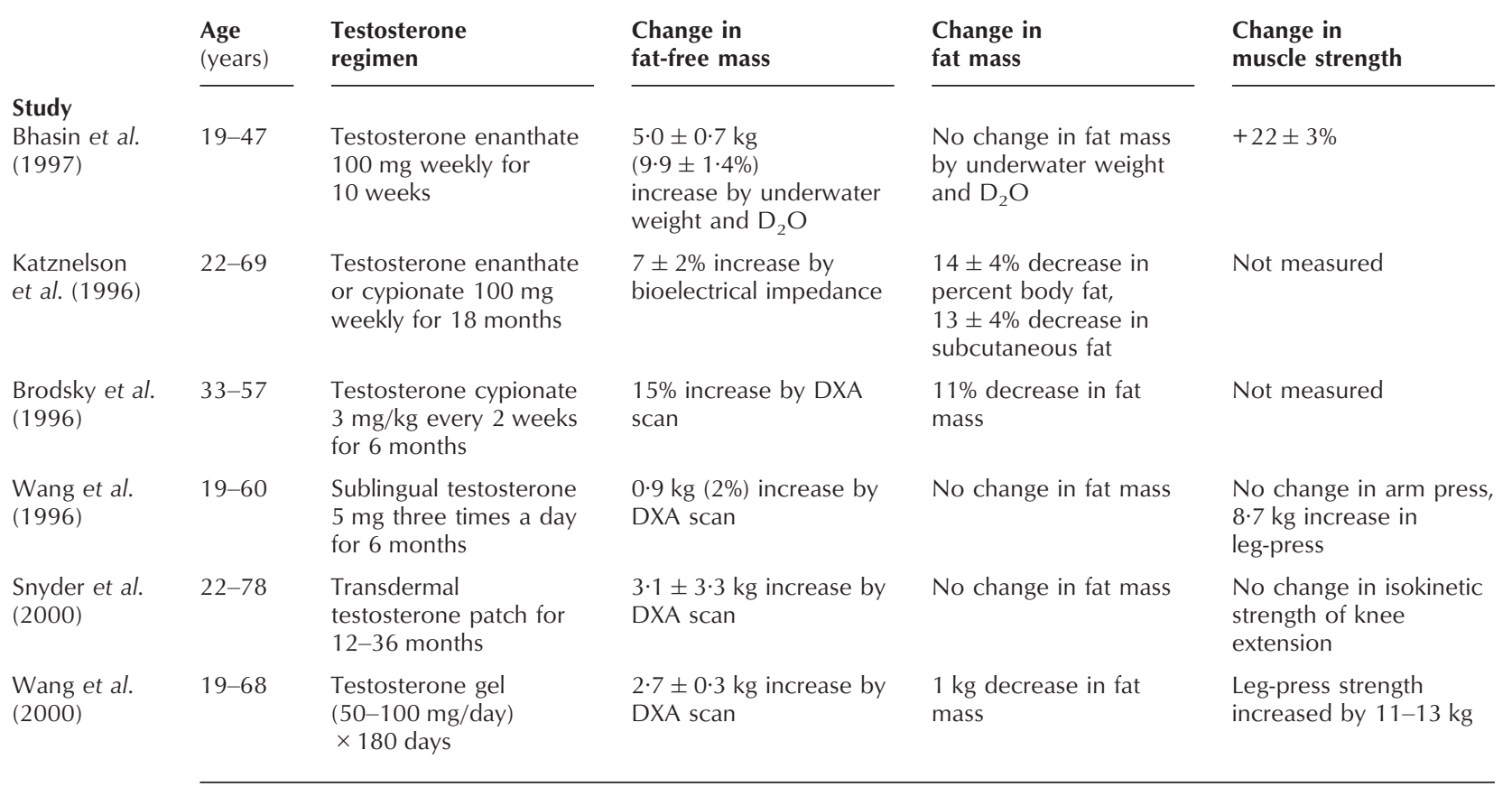

$\mathrm{D}_{2} \mathrm{O}$, deuterium water.

and leg muscle cross-sectional areas, assessed by magnetic resonance imaging, increased significantly. Substantial increases in muscle strength were also noted after treatment.

Brodsky et al. (1996) reported a 15\% increase in fat-free mass and an 11\% decrease in fat mass in hypogonadal men treated with a replacement dose of testosterone enanthate. Their muscle mass increased by $20 \%$ and accounted for $65 \%$ of the increase in fat-free mass. The muscle accretion during testosterone treatment was associated with a $56 \%$ increase in fractional muscle protein synthesis. In another study, a cyclodextrin-complexed testosterone formulation produced a modest increase in fat-free mass $(+0.9 \mathrm{~kg})$ and muscle strength $(+8.7 \mathrm{~kg}$ ) in hypogonadal men (Wang et al. 1996); however, the testosterone dose used in that study was smaller than the doses used in previous studies. Taken together, these studies (Table 1) provide convincing evidence that physiologic androgen replacement in healthy, young hypogonadal men is associated with significant gains in fat-free mass, muscle size and maximal voluntary strength.

\section{Effect of supraphysiologic doses of testosterone on body composition and muscle strength}

Intense controversy persisted until recently with respect to the effects of supraphysiologic doses of androgenic steroids on body composition and muscle strength (Wilson 1988,
Bardin 1996, Casaburi et al. 1996b). We conducted a placebo-controlled, double-blind, randomized clinical trial to assess separately the effects of supraphysiologic doses of testosterone and resistance exercise on fat-free mass, muscle size and strength (Bhasin et al. 1996). Healthy eugonadal men, 19-40 years of age, who were within 15\% of their ideal body weight, were randomly assigned to one of four groups: placebo but no exercise; testosterone but no exercise; placebo plus exercise; testosterone plus exercise. The men received $600 \mathrm{mg}$ testosterone enanthate or placebo weekly for 10 weeks. Serum total and free testosterone concentrations, measured 7 days after each injection, increased fivefold; these were nadir values and serum testosterone concentrations at other times must have been greater. Serum concentrations of luteinizing hormone (LH) were markedly suppressed in the two testosterone-treated groups, but not the placebo-treated groups, providing additional evidence of compliance. Men in the exercise groups underwent weight-lifting exercises three times weekly; the training stimulus was standardized on the basis of the participants' initial one-repetition maximum (1RM) and the sessions were well supervised. Fat-free mass by underwater weighing, muscle size by magnetic resonance imaging, and muscle strength of the arms and legs in bench-press and squat exercises were measured before and after 10 weeks of treatment. The eugonadal men given testosterone alone had greater gains in muscle size in the arm (mean ( \pm s.e.m.) change in 

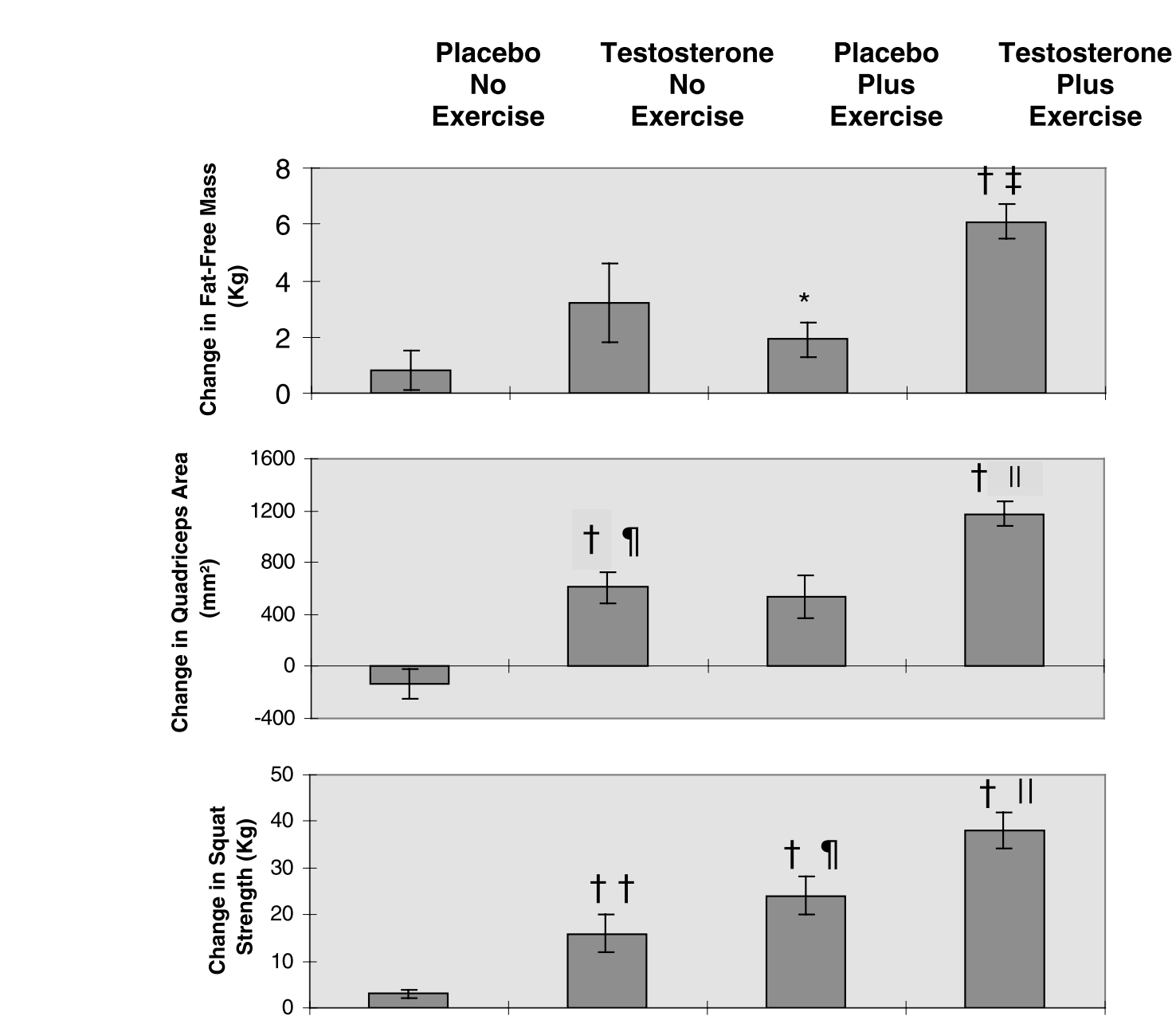

Figure 2 Effect of a supraphysiologic dose of testosterone on fat-free mass, muscle size, and strength in healthy, eugonadal men. Changes from baseline in (mean \pm S.E.). Fat-free mass, quadriceps area, and muscle strength in the squat exercise over the 10 weeks of treatment. Changes significantly different from zero: ${ }^{*} P=0.017 ; \dagger P<0 \cdot 001 ; \dagger+P=0 \cdot 004$. Other changes significantly greater than: $\ddagger$ those in no-exercise groups $(P<0 \cdot 05)$; that in placebo plus no-exercise group $(P<0 \cdot 05)$; $\|$ those in all other groups $(P<0 \cdot 05)$. Adapted with permission from Bhasin et al. (1996).

triceps area $13 \cdot 2 \pm 3 \cdot 3$ compared with $-2 \cdot 1 \pm 2 \cdot 9 \%$, $P<0 \cdot 05$; Fig. 2) and leg (change in quadriceps area $6 \cdot 5 \pm 1 \cdot 3$ compared with $-1 \cdot 0 \pm 1 \cdot 1 \%, P<0 \cdot 05)$ than those given placebo injections. Testosterone treatment was also associated with greater gains in strength in the bench-press (increase $10 \pm 4$ compared with $-1 \pm 2 \%$, $P<0 \cdot 05$; Fig. 2) and squat exercise capacity (increase $19 \pm 6$ compared with $3 \pm 1 \%, P<0 \cdot 05)$ than were placebo-injections. Testosterone and exercise, given together, produced greater increase in fat-free mass $(+9 \cdot 5 \pm 1 \cdot 0 \%)$ and muscle size $(+14 \cdot 7 \pm 3 \cdot 1 \%$ in triceps area and $+14 \cdot 1 \pm 1 \cdot 3 \%$ in quadriceps area) than either placebo or exercise alone, and greater gains in muscle strength $(+24 \pm 3 \%$ in bench-press strength, and $+39 \pm 4 \%$ in squat exercise capacity) than were achieved in either non-exercising group. Serum concentrations of prostate-specific antigen (PSA) did not change during treatment and no abnormalities were detected in the prostate on digital rectal examination during the 10-week treatment period. These results demonstrate that supraphysiologic doses of testosterone, especially when combined with strength training, increase fat-free mass, muscle size and strength in healthy eugonadal men.

Griggs et al. (1989a) administered testosterone enanthate at a dose of $3 \mathrm{mg} / \mathrm{kg}$ per week to healthy, eugonadal men, 19-40 years of age. This was an open-label study that was not placebo-controlled. Muscle mass, estimated from creatinine excretion, increased by a mean of $20 \%$ and total body potassium mass estimated by $40 \mathrm{k}$ counting increased $12 \%$ after 12 weeks of testosterone treatment. In a separate study, a similar dose of testosterone enanthate given for 12 months to men with muscular dystrophy was associated 
Table 2 Effects of testosterone supplementation in older men

\begin{tabular}{|c|c|c|c|c|c|}
\hline \multirow[b]{2}{*}{ Study } & Participants & $\begin{array}{l}\text { Treatment } \\
\text { regimen }\end{array}$ & $\begin{array}{l}\text { Changes in } \\
\text { body composition }\end{array}$ & $\begin{array}{l}\text { Changes in } \\
\text { muscle function }\end{array}$ & Comments \\
\hline & & & & & \\
\hline $\begin{array}{l}\text { Tenover } \\
\text { (1992) }\end{array}$ & $\begin{array}{l}60-75 \text { years, } \\
\text { serum } \\
\text { testosterone } \\
<400 \mathrm{ng} / \mathrm{dl}\end{array}$ & $\begin{array}{l}\text { Testosterone enanthate } \\
100 \text { mg weekly for } \\
3 \text { months }\end{array}$ & $\begin{array}{l}1 \cdot 8 \mathrm{~kg} \text { increase in } \\
\text { fat-free mass; no change } \\
\text { in fat mass }\end{array}$ & $\begin{array}{l}\text { No change in grip } \\
\text { strength }\end{array}$ & $\begin{array}{l}\text { Mild increases in PSA } \\
\text { and hematocrit }\end{array}$ \\
\hline $\begin{array}{l}\text { Morley et al. } \\
(1993)\end{array}$ & $\begin{array}{l}68-89 \text { years, } \\
\text { bioavailable } \\
\text { testosterone } \\
<75 \mathrm{ng} / \mathrm{dl}\end{array}$ & $\begin{array}{l}\text { Testosterone enanthate } \\
200 \text { mg every } 2 \text { weeks } \\
\text { for } 3 \text { months }\end{array}$ & $\begin{array}{l}\text { No change in fat mass } \\
\text { or body weight }\end{array}$ & Increase in grip strength & \\
\hline $\begin{array}{l}\text { Sih et al. } \\
(1997)\end{array}$ & $\begin{array}{l}\text { Healthy men, } \\
51-79 \text { years, } \\
\text { serum } \\
\text { bioavailable } \\
\text { testosterone } \\
<60 \mathrm{ng} / \mathrm{dl}\end{array}$ & $\begin{array}{l}\text { Testosterone cypionate } \\
200 \text { mg every } 2 \text { weeks } \\
\text { for } 12 \text { months }\end{array}$ & $\begin{array}{l}0.9 \mathrm{~cm}(3 \%) \text { increase in } \\
\text { mid-arm circumference; } \\
\text { no change in fat mass }\end{array}$ & $\begin{array}{l}4-5 \mathrm{~kg} \text { increase in grip } \\
\text { strength }\end{array}$ & $\begin{array}{l}\text { No change in PSA, } \\
\text { increase in hematocrit }\end{array}$ \\
\hline $\begin{array}{l}\text { Urban et al. } \\
\text { (1995) }\end{array}$ & $\begin{array}{l}\text { Healthy elderly, } \\
67 \pm 2 \text { years, } \\
\text { testosterone } \\
<480 \mathrm{ng} / \mathrm{dl}\end{array}$ & $\begin{array}{l}\text { Testosterone enanthate } \\
\text { weekly for } 4 \text { weeks to } \\
\text { increase testosterone to } \\
500-1000 \mathrm{ng} / \mathrm{dl}\end{array}$ & $\begin{array}{l}\text { Body composition not } \\
\text { reported }\end{array}$ & $\begin{array}{l}\text { Increase in hamstring } \\
\text { and quadriceps work } \\
\text { per repetition; no } \\
\text { change in endurance }\end{array}$ & $\begin{array}{l}\text { Approximately twofold } \\
\text { increase in fractional } \\
\text { muscle protein synthesis } \\
\text { rate }\end{array}$ \\
\hline $\begin{array}{l}\text { Snyder et al. } \\
\text { (1999) }\end{array}$ & $\begin{array}{l}\text { Healthy older } \\
\text { men, > } 65 \text { years } \\
\text { of age }\end{array}$ & $\begin{array}{l}\text { Scrotal testosterone } \\
\text { patch, } 6 \mathrm{mg} / \text { day for } \\
3 \text { years }\end{array}$ & $\begin{array}{l}\text { Lean body mass } \\
\text { increased by } 1.9 \mathrm{~kg} \text {; fat } \\
\text { mass decreased by } 3 \mathrm{~kg}\end{array}$ & $\begin{array}{l}\text { No change in strength } \\
\text { of knee extension and } \\
\text { flexion }\end{array}$ & $\begin{array}{l}\text { Improved perception of } \\
\text { physical function }\end{array}$ \\
\hline $\begin{array}{l}\text { Tenover } \\
(2000)\end{array}$ & $\begin{array}{l}\text { Healthy, older } \\
\text { men }\end{array}$ & $\begin{array}{l}\text { Testosterone enanthate, } \\
\sim 150 \mathrm{mg} / 2 \text { weeks for } \\
3 \text { years }\end{array}$ & $\begin{array}{l}\text { Fat-free mass increased } \\
\text { and fat mass decreased }\end{array}$ & $\begin{array}{l}\text { Improvements in some } \\
\text { measures of muscle } \\
\text { strength }\end{array}$ & \\
\hline
\end{tabular}

with a $4.9 \mathrm{~kg}$ increase in lean body mass (approximately $10 \%)$ at 3 months; these gains were maintained for 12 months (Griggs et al. 1989b).

Young et al. (1993) examined fat-free mass by dualenergy X-ray absorptiometry (DXA) scan in 13 nonathletic, eugonadal men treated with $200 \mathrm{mg}$ testosterone enanthate weekly for 6 months during the course of a male contraceptive study. This was an open-label study that included untreated men as controls. Testosterone treatment increased serum testosterone concentrations by $90 \%$ and was associated with a $9 \cdot 6 \%$ increase in fat-free mass and a $16 \cdot 2 \%$ decrease in fat mass.

Collectively, these data demonstrate that, when dietary intake and exercise stimulus are controlled, supraphysiologic doses of testosterone produce further increases in fat-free mass and strength in eugonadal men. Thus it is likely that strength training may augment the effects of androgen on the muscle.

\section{Effects of testosterone replacement in older men with low testosterone concentrations}

Several studies (Tenover 1992, 2000, Morley et al. 1993, Sih et al. 1997, Snyder et al. 1999) have now established that the use of testosterone supplementation to increase the testosterone in older men with low testosterone concentrations to values that are mid-normal for healthy young men is associated with a significant increase in lean body mass and a reduction in fat mass (Table 2). Although testosterone supplementation is associated with greater gains in grip strength than are achieved with placebo treatment, it remains unclear whether physiologic testosterone replacement can produce meaningful changes in muscle performance and physical function. In a recent study by Snyder et al. (1999), testosterone treatment of older men did not increase muscle strength or improve physical function, but these men were not uniformly hypogonadal and were unusually fit for their age. In addition, their muscle strength was measured by a method (Biodex dynamometer) that did not demonstrate a response even in frankly hypogonadal younger men treated with testosterone (Snyder et al. 2000). It is possible that testosterone might improve muscle strength and physical function in older men with clearly low testosterone concentrations. These studies also emphasize the need to use muscle function tests that are androgen-responsive, and to control for the confounding influence of the learning effect. 


\section{Effects of androgen replacement on body composition and muscle function in sarcopenia associated with chronic illnesses}

Several different anabolic interventions have been examined in the treatment of human immunodeficiency virus (HIV)-related wasting, including appetite stimulants such as dronabinol and megesterol acetate, anabolic hormones such as human growth hormone (hGH) (Schambelan et al. 1996, Waters et al. 1996), insulin-like growth factor (IGF)-I (Waters et al. 1996) and androgens (Coodley \& Coodley 1997, Grinspoon et al. 1998, Bhasin et al. 1998, 2000, Bhasin \& Javanbakht 1999, Dobs et al. 1999, Sattler et al. 1999, Strawford et al. 1999a,b), and modulators of the immune response such as thalidomide. Dronabinol increases appetite, but has not been shown to increase lean body mass (Beal et al. 1995). Similarly, megesterol acetate treatment produces a modest weight gain but no significant change in lean body mass (Von Roenn et al. 1994). This progestational agent decreases serum testosterone concentrations and may produce symptoms of androgen deficiency.

In the two recently published clinical trials, treatment of HIV-infected men with hGH was associated with a $1.5 \mathrm{~kg}$ increase in lean body mass (Schambelan et al. 1996, Waters et al. 1996). Although greater gains in weight were recorded after 6 weeks of hGH treatment, these gains were not sustained with continued treatment for 12 weeks. It is conceivable that weight gain early in the course of treatment is due to water retention. Administration of $\mathrm{hGH}$ is associated with a high frequency of side effects, including edema, arthralgias, myalgias, and jaw pain. Not surprisingly, the treatment discontinuation rates were high (21-40\%) in the two hGH studies. The annual cost of treating HIV-infected men with hGH is substantially greater than that of testosterone replacement therapy.

Several studies on the effects of androgen supplementation in HIV-infected men have been reported (Coodley \& Coodley 1997, Bhasin et al. 1998, 2000, Bhasin \& Javanbakht 1999, Grinspoon et al. 1998, Dobs et al. 1999, Sattler et al. 1999, Strawford et al. 1999a,b). However, many of these studies were not controlled clinical trials. Most of the studies were of short duration, ranging from 12-24 weeks. Of the five placebo-controlled studies of testosterone replacement in HIV-infected men with weight loss, three (Bhasin et al. 1998, 2000, Grinspoon et al. 1998) demonstrated an increase in fat-free mass and two (Coodley \& Coodley 1997, Dobs et al. 1999) did not. In the three studies (Bhasin et al. 1998, 2000, Grinspoon et al. 1998) that showed gains in fat-free mass, patients with low testosterone concentrations had been specifically selected.

In a recent study (Bhasin et al. 2000), we determined the effects of testosterone replacement, with or without a program of resistance exercise, on muscle strength and body composition in androgen-deficient, HIV-infected men with weight loss and low testosterone concentrations. This was a placebo-controlled, double-blind, randomized, clinical trial in HIV-infected men with serum testosterone less than $350 \mathrm{ng} / \mathrm{dl}$, and weight loss of $5 \%$ or more in the previous 6 months. Sixty-one eligible participants were randomly assigned to one of four groups: placebo, no exercise; testosterone, no exercise; placebo plus exercise; testosterone plus exercise (Bhasin et al. 2000). Placebo or $100 \mathrm{mg}$ testosterone enanthate were given intramuscularly, weekly for 16 weeks. The exercise program was a three times weekly, progressive, supervised strength training program. Effort-dependent muscle strength in five different exercises was measured using the 1RM method. We paid particular attention to having the participants come back to the Exercise Laboratory on two or more occasions until they were familiar with the equipment and technique, and stability of measurement had been achieved. In the placebo only group, muscle strength did not change in any of the five exercises $(-0.3$ to $-4 \cdot 0 \%)$. This indicates that this strategy was effective in minimizing the influence of the learning effect. Men treated with testosterone alone, exercise alone, or combined testosterone and exercise experienced significant increases in maximum voluntary muscle strength in the leg-press (22-30\%, Fig. 3), leg curls (18-36\%), bench press (19-33\%), and latissimus dorsi pulldowns (17-33\%) exercises. The gains in strength in all the exercises were greater in men receiving testosterone or exercise alone than in those receiving placebo alone (Fig. 3). The change in leg-press strength was correlated with change in muscle volume $(r=0.44, P=0.003)$ and change in fat-free mass $(r=0 \cdot 55, P<0 \cdot 001)$.

We conclude that, when the confounding influence of the learning effect is minimized, as we achieved in this study, and appropriate androgen-responsive measures of muscle strength are selected, testosterone replacement is associated with a demonstrable increase in maximal voluntary strength, in HIV-infected men with low testosterone concentrations.

Strength training also promotes gains in lean body mass and muscle strength (Bhasin et al. 1996, 2000). Furthermore, supraphysiologic doses of androgens augment the anabolic effects of resistance exercise on lean body mass and maximal voluntary strength (Strawford et al. 1999b, Sattler et al. 1999).

These data suggest that testosterone can promote weight gain and increase in lean body mass, in addition to muscle strength, in HIV-infected men with low testosterone levels. We do not know, however, whether physiologic androgen replacement can produce meaningful improvement in quality of life, utilization of health care resources, or physical function in HIV-infected men. Emerging data indicate that testosterone does not affect HIV replication, but its effects on virus shedding in the genital tract are not known. 


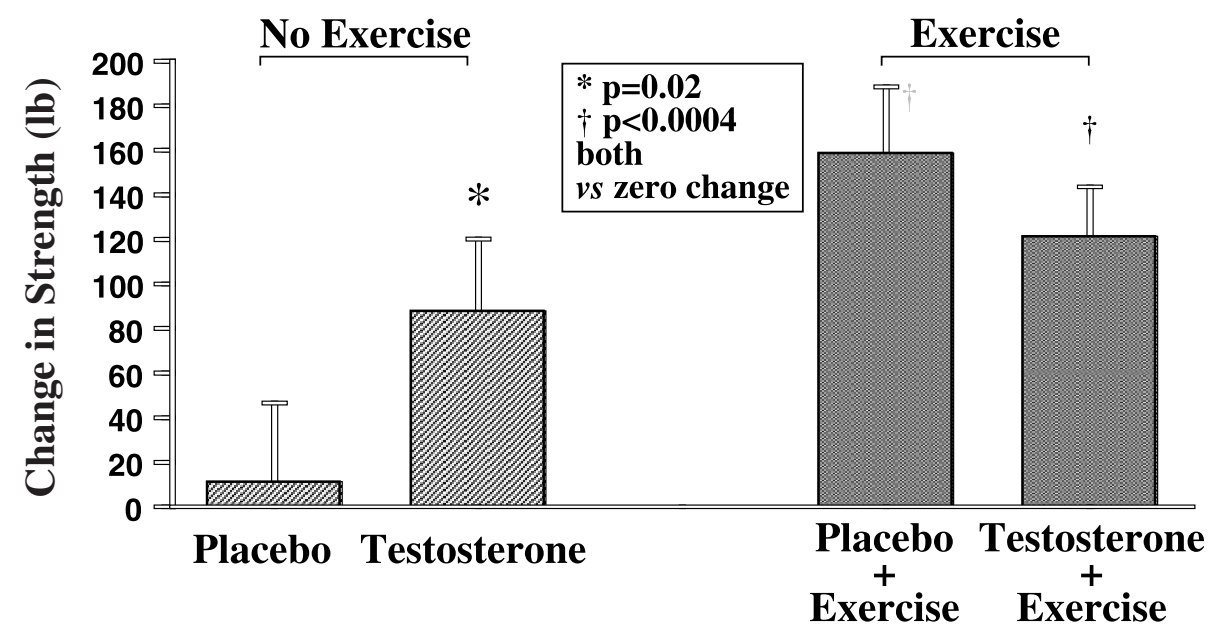

Figure 3 Effects of testosterone replacement with and without a program of resistance exercise in HIV-infected men with weight loss and low testosterone levels: muscle strength assessed by leg-press exercise. Treatment duration was 16 weeks, and the dose of testosterone enanthate was $100 \mathrm{mg}$ weekly. Adapted from Bhasin et al. (2000).

\section{Patterns of androgen abuse by athletes}

Athletes abusing androgens not only use supraphysiologic doses, they often use several androgens simultaneously - a practice that is referred to as stacking (Catlin \& Cowan 1992, Rogol \& Yesalis 1995). For instance, typical replacement doses of testosterone used for hormone replacement of hypogonadal men are $100 \mathrm{mg}$ testosterone enanthate intramuscularly weekly, or 5-10-mg testosterone administered daily by transdermal testosterone patch or gel. Some athletes might use as much as $1 \mathrm{~g}$ or more of testosterone enanthate weekly, and might then combine it with decadurabolin. Because each patch delivers only $5 \mathrm{mg}$ testosterone daily, an individual will have to apply 20 patches daily to achieve testosterone delivery equivalent to $1 \mathrm{~g}$ testosterone enanthate given intramuscularly weekly. Because of the cost and the practical problems associated with applying such a large number of patches, the abuse of the transdermal testosterone patches is less likely to become a significant problem.

Testosterone is cleared rapidly from plasma; the duration of action is, therefore, largely determined by the pharmacokinetics of the formulation used. For instance, testosterone esters such as testosterone enanthate and cypionate, when injected in sesame oil, because of their hydrophobicity, are released slowly from the intramuscular oil depot into the blood stream. De-esterification of testosterone esters occurs rapidly in plasma; it is the slow release of testosterone from the muscle depot that accounts for their extended duration of action. Similarly, daily application of testosterone patches or gel is dictated largely by the rates of release of testosterone from these formulations into the skin and absorption across the skin into the general circulation. After discontinuation of androgen administration, the ability to detect prior androgen use would depend on the type of formulation, the dose, the sensitivity of the detection method, and the type of assay used. After injections of high doses of long-acting testosterone esters, circulating testosterone concentrations and testosterone to epitestosterone ratios in plasma might remain increased for several weeks, but suppression of endogenous LH persists for several weeks to months (Catlin \& Cowan 1992). The biologic effects of testosterone on the muscle are testosterone dose- and concentration-dependent, and are mostly independent of the type of formulation used. Therefore, the gains in muscle mass and strength induced by pharmacologic administration of androgen would be expected to wear off after discontinuation of drug use; however, this issue has not been rigorously studied.

\section{Testosterone effects on athletic performance}

There is agreement that testosterone supplementation increases maximal voluntary strength, but that it does not improve specific tension. Therefore, testosterone would be expected to improve performance in weight-lifting events, because performance in these events is critically dependent upon maximal voluntary strength. It is not surprising that the abuse of androgenic steroids is most prevalent among power lifters. The effects of testosterone on other measures of muscle performance such as fatiguability and power (the rate of force generation) are unknown. Previous studies have failed to demonstrate any improvements in performance in endurance events (Casaburi et al. 1996b). The physiologic basis of the abuse of androgenic steroids by sprint runners or swimmers is not clear. It is possible that 
testosterone might improve athletic performance in sprint events by decreasing reaction time, as testosterone has been shown to regulate neuromuscular transmission (Leslie et al. 1991, Blanco et al. 1997). Others have proposed that testosterone use might enhance recovery from exercise, thus allowing the athletes to train harder. It is also conceivable that testosterone might improve explosive power, an important determinant of performance in sprint and short distance swimming events. This speculation has not been tested. It is fair to state that unequivocal improvements in measures of athletic performance have not been demonstrated in any study.

\section{Testosterone supplementation in other chronic illnesses}

Patients with autoimmune disorders, particularly those receiving glucocorticoids, often experience a reduction in circulating testosterone concentrations, muscle wasting and bone loss (Reid et al. 1985, 1996, McAdams et al. 1986). In a placebo-controlled study, Reid et al. (1996) administered a replacement dose of testosterone to men receiving glucocorticoids. Testosterone replacement was associated with a greater increase in fat-free mass and bone density than were achieved with placebo.

There is a high frequency of low total and free testosterone concentrations, sexual dysfunction, infertility, delayed puberty, and growth failure in patients with end-stage renal disease (Handelsman 1993, 1998). Fat-free mass is decreased and physical function is markedly impaired in men with end-stage renal disease who are receiving maintenance hemodialysis (Johansen et al. 1999). Androgen administration does not consistently improve sexual dysfunction in these patients (Handelsman 1993, 1998). Similarly, the effects of androgen treatment on growth and pubertal development in children with endstage renal disease remain unclear (Jones et al. 1980, Kassmann et al. 1992). Controlled clinical trials of nandrolone decanoate have reported increased hemoglobin concentrations with androgen treatment in men with end-stage renal disease who receive hemodialysis (Williams et al. 1974, Buchwald et al. 1977, Berns et al. 1992, Johansen et al. 1999). Before the advent of erythropoietin, testosterone was commonly used to treat anemia associated with end-stage renal disease. Testosterone increases red cell production by stimulating erythropoietin, augmenting erythropoietin action, and by its direct action on stem cells. Further studies are needed to determine whether testosterone administration can reduce blood transfusion and erythropoietin requirements in patients with end-stage renal disease who are receiving hemodialysis.

Chronic obstructive pulmonary disease (COPD) is a chronic debilitating disease for which there are few effective therapies. Muscle wasting and dysfunction are recognized as correctable causes of exercise intolerance in these patients. It has been speculated that low concentrations of anabolic hormones such as testosterone, growth hormone and IGF-I may contribute to muscle atrophy and dysfunction (Casaburi et al. 1996a). hGH increases nitrogen retention and lean body muscle in patients with COPD; however, the effects of hGH on ventilatory muscle strength and exercise tolerance remain to be established (Pape et al. 1991, Pichard et al. 1996, Burdet et al. 1997). Schols et al. (1995) examined the effects of a low dose of nandrolone or placebo in 217 men and women with COPD; these authors reported modest increases in lean body mass and ventilatory muscle strength.

\section{Effects of testosterone on fat metabolism}

Percent body fat is increased in hypogonadal men (Katznelson et al. 1998). Induction of androgen deficiency in healthy men by administration of a GnRH agonist leads to an increase in fat mass (Mauras et al. 1998). Some studies of young, hypogonadal men have reported a decrease in fat mass with testosterone replacement therapy (Brodsky et al. 1996, Katznelson et al. 1996), whereas others (Wang et al. 1996, Bhasin et al. 1997, Snyder et al. 2000) found no change. In contrast, long-term studies of testosterone supplementation in older men have consistently demonstrated a decrease in fat mass (Snyder et al. 1999). Epidemiologic studies (Barrett-Connor \& Khaw 1988, Seidell et al. 1990) have shown that serum testosterone levels are lower in middle-aged men with visceral obesity. Serum testosterone concentrations correlate inversely with visceral fat area and directly with plasma high-density lipoprotein concentrations. Testosterone replacement in middle-aged men with visceral obesity improves insulin sensitivity and decreases blood glucose and blood pressure (Marin et al. 1992, 1995). Testosterone is an important determinant of regional fat distribution and metabolism in men (Marin et al. 1995), therefore it has been hypothesized that testosterone supplementation might be beneficial in HIV-infected men with the fat-redistribution syndromes.

\section{Role of 5-a-reduction of testosterone in the muscle}

Although the enzyme 5 - $\alpha$-reductase is expressed at low concentrations within muscle (Bartsch et al. 1980), we do not know whether conversion of testosterone to dihydrotestosterone (DHT) is required for mediating the effects of androgen on muscle. Men with benign prostatic hypertrophy who are treated with the 5 - $\alpha$-reductase inhibitor do not experience muscle loss. Similarly, individuals with congenital 5 - $\alpha$-reductase deficiency have normal muscle development at puberty. These data 
suggest that $5-\alpha$-reduction of testosterone is not obligatory for mediating its effects on the muscle.

Sattler et al. (1996) have reported that serum DHT concentrations are lower and the ratio of testosterone to DHT concentrations greater in HIV-infected men than in healthy men. These investigators have proposed that a defect in testosterone to DHT conversion may contribute to wasting in a subset of HIV-infected men. If this hypothesis were true, then it would be rational to treat such patients with DHT rather than testosterone. A DHT gel is currently under clinical investigation. However, unlike testosterone, DHT is not aromatized to estradiol. Therefore, there is concern that suppression of endogenous testosterone and estradiol production by exogenous DHT may produce osteoporosis.

\section{Mechanisms of the anabolic effects of testosterone on muscle}

Several studies are in agreement that testosterone produces muscle hypertrophy by increasing fractional muscle protein synthesis (Urban et al. 1995, Brodsky et al. 1996). However, the molecular basis of this anabolic effect is not known. Urban et al. (1995) have proposed that testosterone stimulates the expression of IGF-I and downregulates IGF binding protein-4 in the muscle. Reciprocal changes in IGF-I and its binding protein thus provide a potential mechanism for amplifying the anabolic signal. It is not clear whether the anabolic effects of supraphysiologic doses of testosterone are mediated through an androgenreceptor-mediated mechanism. In vitro binding studies (Saartok et al. 1984) suggest that the androgen receptors in most tissues are either saturated or downregulated at testosterone concentrations that are at the lower end of the normal male range. Therefore, it is possible that the supraphysiologic doses of androgen produce muscle hypertrophy through androgen-receptor-independent mechanisms, such as through an antiglucocorticoid effect (Konagaya \& Max 1986, Wu 1997). However, androgenic steroids have very low affinity for binding to glucocorticoid receptor; therefore, androgen modulation of glucocorticoid function through a post-receptor mechanism or through regulation of glucocorticoid-mediated gene expression has been postulated (Hickson et al. 1990, Tincello et al. 1997). We cannot exclude the possibility that some effects of androgen may be mediated through non-classical binding sites. The effects of testosterone on the muscle are modulated by a number of other factors such as the genetic background, growth hormone secretory status (Fryburg et al. 1997), nutrition, exercise, cytokines, thyroid hormones, and glucocorticoids. Testosterone may also affect muscle function by its effects on neuromuscular transmission (Leslie et al. 1991, Blanco et al. 1997). Finally, it is possible that athletes using supraphysiologic doses of testosterone might train harder because of the putative behavioral effects of testosterone; this could indirectly promote muscle hypertrophy.

The structure-activity relationships of androgenic steroids are not well understood. Until recently, it remained unclear whether the myotropic activity of androgens could be dissociated from their androgenic activity (Wilson 1988). Receptor binding studies in the rat seminal vesicle have suggested that the differences in the effects of nandrolone, an androgenic steroid that has been claimed to be more anabolic than androgenic in its actions, and testosterone, the prototypical androgen, might be related to the fact that 5 - $\alpha$-reduction increases the affinity of testosterone, but decreases the affinity of nandrolone for the androgen receptor (Bergink et al. 1985). Therefore, relative to testosterone, nandrolone might have a greater proportional effect in tissues with low 5- $\alpha$-reductase activity such as the muscle, in comparison with tissues with high 5 - $\alpha$-reductase activity such as the prostate (Bergink et al. 1985, Toth \& Zakar 1982). More recent data suggest that the tissue specificity of androgen action is determined by the combinatorial recruitment and activity of tissue-specific co-repressors and co-activators (NegroVilar 1999). By means of high-throughput molecular screening strategies, novel families of non-steroidal molecules with tissue and function selectivity have been identified (Negro-Vilar 1999); these observations have provided strong evidence that it may be possible to dissociate the myotropic and androgenic properties.

\section{Effects of androgens on body composition in women}

Supraphysiologic doses of testosterone increase nitrogen retention and promote weight gain in healthy, menstruating women (Kenyon et al. 1940). However, we do not know whether physiologic testosterone replacement can increase muscle mass and strength in older women or in women with clinical disorders associated with androgen deficiency. There are two assumptions that underlie the use of testosterone as an anabolic agent in sarcopenia in women: first, the testosterone dose-response curve is different in women and in men; second, clinically meaningful anabolic effects can be achieved in women, without the virilizing side effects. Both of these assumptions remain unsubstantiated. The data on the effects of androgen in women are very limited and difficult to interpret for several reasons. The existing testosterone formulations were designed to provide testosterone in men, and therefore most studies have used supraphyiologic doses of testosterone. Commercially available testosterone assays lack the sensitivity and precision to measure the low total and free testosterone concentrations in women. Because of the paucity of normal data, it is difficult to define androgen deficiency in women.

Women with polycystic ovary syndrome with high testosterone concentrations have greater fat-free mass than 
age-matched controls. Davis et al. (2000) have shown that addition of testosterone to a regimen of estrogen replacement in post-menopausal women is associated with greater increments in fat-free mass than is achieved with estrogen alone.

Grinspoon et al. (1998), in a pilot study of HIV-infected women with weight loss, reported that a nominal dose of $150 \mu \mathrm{g}$ testosterone delivered by the transdermal matrix patch was associated with positive trends in weight gain and some domains of health-related quality of life. However, the fat-free mass was not significantly changed. Therefore, it is not clear whether physiologic testosterone replacement can produce clinically meaningful changes in body composition and muscle function in women with androgen deficiency.

\section{Summary}

Replacement doses of testosterone when given to healthy hypogonadal men, and supraphysiologic doses when given to eugonadal men, increase fat-free mass, muscle size and strength. Testosterone supplementation in older men with low testosterone concentrations, and in HIV-infected men with weight loss and low testosterone concentrations is also associated with gains in fat-free mass and muscle strength. However, we do not know whether testosterone supplementation can improve physical function or other health-related outcomes in sarcopenia associated with aging or chronic illness. In spite of the widespread abuse of androgenic steroids by athletes and recreational body builders, the effects of testosterone on athletic performance are not well understood.

\section{References}

Bardin CW 1996 The anabolic action of testosterone. New England Journal of Medicine 335 52-53.

Barrett-Connors E \& Khaw K-T 1988 Endogenous sex-hormones and cardiovascular disease in men. A prospective population-based study. Circulation 78 539-545.

Bartsch W, Krieg M \& Voigt KD 1980 Quantitation of endogenous testosterone, 5-alpha-dihydrotestosterone and 5-alpha-androstane-3-alpha, 17-beta-diol in subcellular fractions of the prostate, bulbocavernosus/levator ani muscle, skeletal muscle, and heart muscle of the rat. Journal of Steroid Biochemistry 13 259-267.

Beal JE, Olson R, Laubenstein L, Morales JO, Bellman P, Yangco B, Lefkowitz L, Plasse TF \& Shepard KV 1995 Dronabinol as a treatment for anorexia associated with weight loss in patients with AIDS. Journal of Pain and Symptom Management 10 89-97.

Bergink EW, Janssen PS, Turpijn EW \& van der Vies J 1985 Comparison of the receptor binding properties of nandrolone and testosterone under in vitro and in vivo conditions. Journal of Steroid Biochemistry 22 831-836.

Berns JS, Rudnick MR \& Cohen RM 1992 A controlled trial of recombinant erythropoieitin and nandrolone decanoate in the treatment of anemia in patients on chronic hemodialysis. Clinical Nephrology 37 264-267.
Bhasin S \& Javanbakht M 1999 Can androgen therapy replete lean body mass and improve muscle function in wasting associated with human immunodeficiency virus infection? Journal of Parenteral and Enteral Nutrition 23 S195-S201.

Bhasin S, Storer TW, Berman N, Callegari C, Clevenger BA, Phillips J, Bunnell T, Tricker R, Shirazi A \& Casaburi R 1996 The effects of supraphysiologic doses of testosterone on muscle size and strength in men. New England Journal of Medicine 335 1-7.

Bhasin S, Storer TW, Berman N, Yarasheski K, Phillips J, Clevenger B, Lee WP \& Casaburi R 1997 A replacement dose of testosterone increases fat-free mass and muscle size in hypogonadal men. Journal of Clinical Endocrinology and Metabolism 82 407-413.

Bhasin S, Storer TW, Asbel-Sethi N, Kilbourne A, Hays R, SinhaHikim I, Shen R, Arver S \& Beall G 1998 Effects of testosterone replacement with a non-genital, transdermal system, Androderm, in human immunodeficiency virus-infected men with low testosterone levels. Journal of Clinical Endocrinology and Metabolism 83 3155-3162.

Bhasin S, Storer TW, Javanbakht M, Berman N, Yarasheski KE, Phillips J, Dike M, Sinha-Hikim I, Shen R, Hays RD \& Beall G 2000 Effects of testosterone replacement and resistance exercise on muscle strength, and body composition in human immunodeficiency virus-infected men with weight loss and low testosterone levels. Journal of the American Medical Association 283 763-770.

Blanco CE, Popper P \& Micevych P 1997 Anabolic-androgenic steroid induced alterations in choline acetyltransferase messenger RNA levels of spinal cord motoneurons in the male rat. Neuroscience 78 973-882.

Brodsky IG, Balagopal P \& Nair KS 1996 Effects of testosterone replacement on muscle mass and muscle protein synthesis in hypogonadal men-a Clinical Research Center Study. Journal of Clinical Endocrinology and Metabolism 81 3469-3475.

Bross R, Casaburi R, Storer TW \& Bhasin S 1998 Androgen effects on body composition and muscle function: implications for the use of androgens as anabolic agents in sarcopenic states. Bailliè res Clinical Endocrinology and Metabolism 12 365-378.

Buchwald D, Argyres S, Easterling RE, Oelshlegel FJ Jr, Brewer GJ, Schoomaker EB, Abbrecht PH, Williams GW \& Weller JM 1977 Effect of nandrolone decanoate on the anemia of chronic hemodialysis patients. Nephron 18 232-238.

Burdet L, de Muralt B, Schutz Y, Pichard C \& Fitting JW 1997 Administration of growth hormone to underweight patients with chronic obstructive pulmonary disease. A prospective, randomized, controlled study. American Journal of Respiratory and Critical Care Medicine 156 1800-1806.

Casaburi R, Goren S \& Bhasin S 1996a Substantial prevalence of low anabolic hormone levels in COPD patients undergoing rehabilitation. American Journal of Respiratory and Critical Care Medicine 153 A128 (Abstract).

Casaburi R, Storer T \& Bhasin S $1996 b$ Androgen effects on body composition and muscle performance. In Pharmacology, Biology, and Clinical Applications of Androgens: Current Status and Future Prospects, pp 283-288. Eds S Bhasin, H Gabelnick, JM Spieler, RS Swerdloff \& C Wang. New York, NY: Wiley-Liss.

Catlin DH \& Cowan DA 1992 Detecting testosterone administration. Clinical Chemistry 38 1685-1686.

Coodley GO \& Coodley MK 1997 A trial of testosterone therapy for HIV-associated weight loss. AIDS 11 1347-1352.

Davis SR, Walker KZ \& Strauss BJ 2000 Effects of estradiol with and without testosterone on body composition and relationships with lipids in postmenopausal women. Menopause 7 395-401.

Dobs AS, Cofrancesco J, Nolten WE, Danoff A, Anderson R, Hamilton CD, Feinberg J, Seekins D, Yangco B \& Rhame F 1999 The use of a transscrotal testosterone delivery system in the treatment of patients with weight loss related to human immunodeficiency virus infection. American Journal of Medicine 107 126-132. 
Fryburg DA, Weltman A, Jahn LA, Weltman J, Samojlik E, Hintz RL \& Veldhuis JD 1997 Short-term modulation of the androgen milieu alters pulsatile, but not exercise- or growth hormone (GH)-releasing hormone-stimulated GH secretion in healthy men: impact of gonadal steroid and GH secretory changes on metabolic outcomes. Journal of Clinical Endocrinology and Metabolism 82 3710-3719.

Griggs RC, Kingston W, Josefowicz RF, Herr BE, Forbes G \& Halliday D 1989a Effect of testosterone on muscle mass and muscle protein synthesis. Journal of Applied Physiology 66 498-503.

Griggs RC, Pandya S, Florence JM, Brooke MH, Kingston W, Miller JP, Chutkow J, Herr BE \& Moxley RT 1989b Randomized controlled trial of testosterone in myotonic dystrophy. Neurology 39 219-222.

Grinspoon S, Corcoran C, Askari H, Schoenfeld D, Wolf L, Burrows B, Walsh M, Hayden D, Parlman K, Anderson E, Basgoz N \& Klibanski A 1998 Effects of androgen administration in men with the AIDS wasting syndrome: a randomized, double-blind, placebo-controlled trial. Annals of Internal Medicine 129 18-26.

Handelsman DJ \& Dong Q 1993 Hypothalamic-pituitary-gonadal axis in chronic renal failure. Endocrinology and Metabolism Clinics of North America 22 145-161.

Handelsman DJ \& Liu PY 1998 Androgen therapy in chronic renal failure. Bailliè res Clinical Endocrinology and Metabolism 12 485-500.

Hickson RC, Czerwinski SM, Falduto MT \& Young AP 1990 Glucocorticoid antagonism by exercise and androgenic-anabolic steroids. Medicine and Science in Sports and Exercise 199022 331-340.

Johansen KL, Mulligan K \& Schambelan M 1999 Anabolic effects of nandrolone decanoate in patients receiving dialysis: a randomized controlled trial [see comments]. Journal of the American Medical Association 281 1275-1281.

Jones RW, El Bishti MM, Bloom SR, Burke J, Carter JE, Counahan R, Dalton RN, Morris MC \& Chantler C 1980 The effects of anabolic steroids on growth, body composition, and metabolism in boys with chronic renal failure on regular hemodialysis. Journal of Pediatrics 97 559-566.

Kassmann K M, Rappaport R \& Broyer M 1992 The short term effect of testosterone on growth in boys on hemodialysis. Clinical Nephrology 37 148-154.

Katznelson L, Finkelstein JS, Schoenfeld DA, Rosenthal DI, Anderson EJ \& Klibanski A 1996 Increase in bone density and lean body mass during testosterone administration in men with acquired hypogonadism. Journal of Clinical Endocrinology and Metabolism $\mathbf{8 1}$ 4358-4365.

Katznelson L, Rosenthal DI, Rosol MS, Anderson EJ, Hayden DL, Schoenfeld DA \& Klibanski A 1998 Using quantitative CT to assess adipose distribution in adult men with acquired hypogonadism. American Journal of Roentgenology 170 423-427.

Kenyon AT, Knowlton K, Sandiford I, Kock FC \& Lotwin G 1940 A comparative study of the metabolic effects of testosterone propionate in normal men and women and in eunuchoidism. Endocrinology 26 $26-45$.

Kochakian CD 1950 Comparison of protein anabolic properties of various androgens in the castrated rat. American Journal of Physiology $60553-558$.

Konagaya M \& Max SR 1986 A possible role for endogenous glucocorticoid in orchiectomy-induced atrophy of the rat levator ani muscle: studies with RU38486, a potent glucocorticoid antagonist. Journal of Steroid Biochemistry 25 305-311.

Leslie M, Forger NG \& Breedlove SM 1991 Sexual dimorphism and androgen effects on spinal motoneurons innervating the rat flexor digitorum brevis. Brain Research 561 269-273.

McAdams MR, White RH \& Chipps BE 1986 Reduction of serum testosrone levels during chronic glucocorticoid therapy. Annals of Internal Medicine 104 648-651.

Marin P, Krotkiewski M \& Bjorntorp P 1992 Androgen treatment of middle-aged, obese men: effects on metabolism, muscle, and adipose tissues. European Journal of Medicine 1 329-336.
Marin P, Oden B \& Bjorntorp P 1995 Assimilation and mobilization of triglycerides in subcutaneous abdominal and femoral adipose tissue in vivo in men: effects of androgens. Journal of Clinical Endocrinology and Metabolism 80 239-243.

Mauras N, Hayes V, Welch S, Rini A, Helgeson K, Dokler M, Veldhuis JD \& Urban RJ 1998 Testosterone deficiency in young men: marked alterations in whole body protein kinetics, strength and adiposity. Journal of Clinical Endocrinology and Metabolism $\mathbf{8 3}$ 1886-1892.

Morley JE, Perry HM 3rd, Kaiser FE, Kraenzle D, Jensen J, Houston K, Mattammal M \& Perry HM Jr 1993 Effects of testosterone replacement therapy in old hypogonadal males: a preliminary study. Journal of the American Geriatric Society 41 149-152.

Morley JE, Kaiser F, Raum WJ, Perry HM 3rd, Flood JF, Jensen J, Silver AJ \& Roberts E 1997 Potentially predictive and manipulable blood serum correlates of aging in the healthy human male: progressive decreases in bioavailable testosterone, dehydroepiandrosterone sulfate, and the ratio of insulin-like growth factor 1 to growth hormone. PNAS 94 7537-7542.

Negro-Vilar A 1999 Selective androgen receptor modulators (SARMs): a novel approach to androgen therapy for the new millennium. Journal of Clinical Endocrinology and Metabolism $\mathbf{8 4}$ $3459-3462$.

Pape GS, Friedman M, Underwood LE \& Clemmons DR 1991 The effect of growth hormone on weight gain and pulmonary function in patients with chronic obstructive lung disease. Chest $\mathbf{9 9}$ 1495-1500.

Pichard C, Kyle U \& Chevrolet JC 1996 Lack of effects of recombinant growth hormone on muscle function in patients requiring prolonged mechanical ventilation: a prospective randomized controlled study. Critical Care Medicine 24 403-413.

Reid IR, Ibbertson HK, France JT \& Pybus J 1985 Plasma testosterone concentrations in asthmatic men treated with glucocorticoids. British Medical Journal 291 574-577.

Reid IR, Wattie DJ, Evans MC \& Stapleton JP 1996 Testosterone therapy in glucocorticoid-treated men. Archives of Internal Medicine 156 1173-1177.

Rogol AD \& Yesalis CE 3rd 1992 Clinical review 31: anabolicandrogenic steroids and athletes: what are the issues? Journal of Clinical Endocrinology and Metabolism 74 465-469.

Saartok T, Dahlberg E \& Gustaffsson JA 1984 Relative binding affinity of anabolic-androgenic steroids, comparison of the binding to the androgen receptors in skeletal muscle and in prostate as well as sex hormone binding globulin. Endocrinology 114 2100-2107.

Sattler FR, Antonipillai I, Allen J \& Horton R 1996 Wasting and sex hormones: evidence for the role of dihydrotestosterone in AIDS patients with weight loss. Proceedings of the XI International Conference on AIDS. Vancouver, Canada. Abstract Tu.B.2376.

Sattler FR, Jaque SV, Schroeder ET, Olson C, Dube MP, Martinez C, Briggs W, Horton R \& Azen S 1999 Effect of pharmacological doses of nandrolone decanoate and progressive resistance training in immunodeficient patients infected with the human immunodeficiency virus. Journal of Clinical Endocrinology and Metabolism 84 1268-1276.

Schambelan M, Mulligan K, Grunfeld C, Daar ES, LaMarca A, Kotler DP, Wang J, Bozzette SA \& Breitmeyer JB 1996 Recombinant growth hormone in patients with HIV-associated wasting. Annals of Internal Medicine 125 873-882.

Schols AMW, Soeters PB \& Mostert R 1995 Physiologic effects of nutritional support and anabolic steroids in patients with chronic obstructive pulmonary disease. American Journal of Respiratory and Critical Care Medicine 152 1268-1274.

Seidell J, Bjorntorp P, Sjostrom L, Kvist H \& Sannerstedt R 1990 Visceral fat accumulation in men is positively associated with insulin, glucose and C-peptide levels, but negatively with testosterone levels. Metabolism 39 897-901. 
Sih R, Morley JE, Kaiser FE, Perry HM 3rd, Patrick P \& Ross C 1997 Testosterone replacement in older hypogonadal men: a 12-month randomized controlled trial [see comments]. Journal of Clinical Endocrinology and Metabolism 82 1661-1667.

Snyder PJ, Peachey H, Hannoush P, Berlin JA, Loh L, Lenrow DA, Holmes JH, Dlewati A, Santanna J, Rosen CJ \& Strom BL 1999 Effect of testosterone treatment on body composition and muscle strength in men over 65. Journal of Clinical Endocrinology and Metabolism 84 2647-2653.

Snyder PJ, Peachey H, Berlin JA, Hannoush P, Haddad G, Dlewati A, Santanna J, Loh L, Lenrow DA, Holmes JH, Kapoor SC, Atkinson LE \& Strom BL 2000 Effects of testosterone replacement in hypogonadal men. Journal of Clinical Endocrinology and Metabolism $852670-2677$.

Strawford A, Barbieri T, Neese R, Van Loan M, Christiansen M, Hoh R, Sathyan G, Skowronski R, King J \& Hellerstein M 1999a Effects of nandrolone decanoate therapy in borderline hypogonadal men with HIV-associated weight loss. Journal of Acquired Immune Deficiency Syndromes and Human Retrovirolgy 20 137-146.

Strawford A, Barbieri T, Van Loan M, Parks E, Catlin D, Barton N, Neese R, Christiansen M, King J \& Hellerstein MK 1999 b Resistance exercise and supraphysiologic androgen therapy in eugonadal men with HIV-related weight loss. Journal of the American Medical Association 281 1282-1290.

Tenover JS 1992 Effects of testosterone supplementation in the aging male. Journal of Clinical Endocrinology and Metabolism $\mathbf{7 5}$ 1092-1098.

Tenover JL 2000 Experience with testosterone replacement in the elderly. Mayo Clinic Proceedings 75 (Suppl.) S77-S81; discussion S82.

Tincello DG, Saunders PT, Hodgins MB, Simpson NB, Edwards CR, Hargreaves TB \& Wu FC 1997 Correlation of clinical, endocrine, and molecular abnormalities with in vivo responses to high-dose testosterone in patients with partial androgen insensitivity syndrome. Clinical Endocrinology 46 497-506.

Toth M \& Zakar T 1982 Relative binding affinities of testosterone, 19-nortestosterone and their 5 alpha-reduced derivatives to the androgen receptor and to other androgen-binding proteins: a suggested role of 5 alpha-reductive steroid metabolism in the dissociation of 'myotropic' and 'androgenic' activities of 19-nortestosterone. Journal of Steroid Biochemistry 17 653-660.
Urban RJ, Bodenburg YH, Gilkison C, Foxworth J, Coggan AR, Wolfe RR \& Ferrando A 1995 Testosterone administration to elderly men increases skeletal muscle strength and protein synthesis. American Journal of Physiology 269 E820-E826.

Von Roenn JH, Armstrong D, Kotler DP, Cohn DL, Klimas NG, Tchekmedyian NS, Cone L, Brennan PJ \& Weitzman SA 1994 Megastrol acetate in patients with AIDS-related cachexia. Annals of Internal Medicine 121 393-399.

Wang C, Eyre DR, Clark R, Kleinberg D, Newman C, Iranmanesh A, Veldhuis J, Dudley RE, Berman N, Davidson T, Barstow TJ, Sinow R, Alexander G \& Swerdloff RS 1996 Sublingual testosterone replacement improves muscle mass and strength, decreases bone resorption, and increases bone resorption markers in hypogonadal men - a Clinical Research Center Study. Journal of Clinical Endocrinology and Metabolism 81 3654-3662.

Wang C, Swerdloff RS, Iranmanesh A, Dobs A, Snyder PJ, Cunningham G, Matsumoto AM, Weber T \& Berman N 2000 Transdermal testosterone gel improves sexual function, mood, muscle strength, and body composition parameters in hypogonadal men. Testosterone Gel Study Group. Journal of Clinical Endocrinology and Metabolism 85 2839-2853.

Waters D, Danska J, Hardy K \& Koster F 1996 Recombinant growth hormone, insulin-like growth factor-1, and combination therapy in AIDS-associated wasting. Annals of Internal Medicine 125 865-872.

Williams JL, Stein JH \& Ferris TF 1974 Nandrolone decanoate therapy for patients receiving hemodialysis. A controlled study. Archives of Internal Medicine 134 289-292.

Wilson JD 1988 Androgen abuse by athletes. Endocrine Reviews 9 181-199.

Wu FC 1997 Endocrine aspects of anabolic steroids. Clinical Chemistry 43 1289-1292.

Young NR, Baker HWG, Liu G \& Seeman E 1993 Body composition and muscle strength in healthy men receiving testosterone enanthate for contraception. Journal of Clinical Endocrinology and Metabolism 77 1028-1032.

Received 2 November 2000

Accepted 18 January 2001 